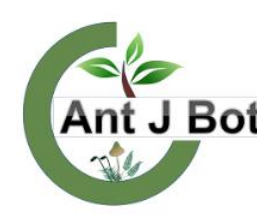

Received : 05.07.2018 Accepted : 18.09.2018 Online : :02.12.2018

\section{In Vitro rapid propagation of an aquatic plant Pogostemon erectus (Dalzell) Kuntze}

\author{
Muhammet DOGAN*(i) \\ Karamanoglu Mehmetbey University University, Kamil Ozdag Faculty of Science Faculty, Department of \\ Biology, Karaman, Turkey \\ *mtdogan1@gmail.com
}

\section{Sucul bir bitki olan Pogostemon erectus (Dalzell) Kuntze'un In Vitro hızlı çoğaltımı}

\begin{abstract}
The aim of this study is to investigate the multiple and rapid production of Pogostemon erectus (Dalzell) Kuntze by tissue culture techniques. The shoot tip and nodal explants of $P$. erectus were isolated and then cultured in Murashige and Skoog (1962) (MS) nutrient media containing thidiazuron (TDZ) and 2,4-Dichlorophenoxyacetic acid (2,4-D) in different combinations. The first shoot formation on the explants was observed on day 15. The number of shoots per explant ranged from 2.85 to 29.39 in the shoot tip explants and from 2.72 to 32.24 in the nodal explants. The maximum number of shoots per explant was obtained in the MS medium containing $0.20 \mathrm{mg} / \mathrm{L} \mathrm{TDZ}+0.10 \mathrm{mg} / \mathrm{L}$ 2,4-D for shoot tip explant (29.39) and in the MS medium containing $0.10 \mathrm{mg} / \mathrm{L} \mathrm{TDZ}+0.10 \mathrm{mg} / \mathrm{L} 2,4-\mathrm{D}$ for nodal explant $(32.24)$. The longest shoots in the shoot tip $(1.76 \mathrm{~cm})$ and nodal $(1.64 \mathrm{~cm})$ explants were determined in MS medium supplemented with $0.10 \mathrm{mg} / \mathrm{L} \mathrm{TDZ}+0.10 \mathrm{mg} / \mathrm{L} 2,4-\mathrm{D}$. Regenerated shoots were rooted in MS medium supplemented with $0.25 \mathrm{mg} / \mathrm{L}$ indol-3yl acetic acid (IAA), and then acclimatized to aquarium conditions.
\end{abstract}

Key words: In vitro, Pogostemon erectus, Shoot regeneration, TDZ, Tissue culture

Özet: Bu çalışmanın amacı, Pogostemon erectus (Dalzell) Kuntze'un doku kültürü teknikleri ile çoklu ve hızlı üretimini araştırmaktır. $P$. erectus'un sürgün ucu ve nodal eksplantları izole edilmiş ve daha sonra farklı kombinasyonlarda thidiazuron (TDZ) ve 2,4-Diklorofenoksiasetik asit (2,4-D) içeren Murashige ve Skoog (1962) (MS) besin ortamında kültüre alınmıştır. Eksplantlardaki ilk sürgün oluşumu 15. günde gözlenmiştir. Eksplant başına sürgün sayısı, sürgün ucu eksplantlarında 2.85 ila 29.39 ve nodal eksplantlarında 2.72 ila 32.24 arasında sıralanmıştır. Eksplant başına maksimum sürgün sayısı sürgün ucu eksplantı için (29.39) $0.20 \mathrm{mg} / \mathrm{L} \mathrm{TDZ}+0.10 \mathrm{mg} / \mathrm{L}$ 2,4-D içeren MS ortamında ve nodal eksplant için $0.10 \mathrm{mg} / \mathrm{L}$ TDZ +0.10 $\mathrm{mg} / \mathrm{L}$ 2,4-D içeren MS ortamında (32.24) elde edilmiştir. En uzun sürgünler, sürgün ucu $(1.76 \mathrm{~cm})$ ve nodal $(1.64 \mathrm{~cm})$ eksplantlarında $0.10 \mathrm{mg} / \mathrm{L} \mathrm{TDZ}+0.10 \mathrm{mg} / \mathrm{L}$ 2,4-D ile desteklenmiş MS ortamında belirlenmiştir. Rejenere sürgünler, 0.25 $\mathrm{mg} / \mathrm{L}$ Indol-3-asetik asit (IAA) ile takviye edilmiş MS ortamında köklendirilmiş ve ardından akvaryum koşullarına alıştırılmıştır.

Anahtar Kelimeler: In vitro, Pogostemon erectus, Sürgün rejenerasyonu, TDZ, Doku kültürü

\section{Introduction}

Plant tissue culture is defined as the growth of plant parts isolated from the main plant in an artificial nutrient medium under sterile conditions. This technique is mainly due to the totipotency of the plant cell. Totipotency is the ability of a single cell to generate whole genome with cell divisions (Neumann et al., 2009; Hussain et. al., 2012).

The plant tissue culture medium should contain all the nutrients needed to grow a plant normally. This nutrient medium is mainly; macronutrients, micronutrients, vitamins, other organic components, plant growth regulators, carbon source and some gelling agents (Murashige and Skoog, 1962). Murashige and Skoog (MS) nutrient media are the most used nutrient medium for in vitro production of many plant species. Similarly, Lachenalia viridiflora (Kumar et al., 2016), Rotala rotundifolia (Buch-Ham. ex Roxb) Koehne (Dogan, 2017a), Urginea altissima (L.f.) Baker (Baskaran et al., 2017), Ceratophyllum demersum L. (Emsen and Dogan, 2018), Brassica napus L. (Nazi et al., 2018), Ophiorrhiza mungos L. var. angustifolia (Thw.) Hook. f. (Krishnan et al., 2018), Hybanthus enneaspermus (L.) F. Muell. (Shekhawat and Manokari, 2018) were propagated using the MS nutrient medium.
The $\mathrm{pH}$ of the nutrient medium significantly affects the activities of plant growth regulators and plant growth. For this reason, the $\mathrm{pH}$ of the nutrient medium is adjusted between 5.4 and 5.8. In addition, plant parts, plant growth regulators and nitrogen sources in the nutrient media are also very important for shoot regeneration. Auxins, cytokinins and gibberellins are the most commonly used plant growth regulators. The variety and concentration of the plant growth regulator may differ according to the cultivated plant species and explant varieties (Hussain et al., 2012). In addition, the correct selection of explant types (shoot tip, node, internode, etc.) has an important effect on the success of tissue culture (George et al., 2008).

The purpose of this study is to propagate rapid and multiple production of tissue culture techniques of Pogostemon erectus (Dalzell) Kuntze. Thus, the shoot tip and nodal explants of $P$. erectus were transferred to culture media containing different thidiazuron (TDZ) and 2,4-Dichlorophenoxyacetic acid (2,4-D) combinations. The effects of these hormones on in vitro production have been examined. 


\section{Materials and Method}

Pogostemon erectus (Dalzell) Kuntze's surface sterilization has been sterilized according to the procedure previously done by Dogan (2017b). Sterilized shoot tip and nodal explants were cultured in MS (Murashige and Skoog, 1962) basal medium containing vitamins (Table 1) at $24^{\circ} \mathrm{C}$ for 16 hours in light and 8 hours in dark photoperiod. The shoot tip and nodal explants from 4 week old plants grown in this culture medium were transferred to MS medium supplemented with $0.10 \mathrm{mg} / \mathrm{L}$ 2,4-Dichlorophenoxyacetic acid (2,4-D) and 0.10, 0.20, 0.40 and $0.80 \mathrm{mg} / \mathrm{L}$ thidiazuron (TDZ) combinations.

Table 1. The content of Murashige and Skoog (1962) basic nutrient medium

\begin{tabular}{|c|c|c|}
\hline \multicolumn{2}{|c|}{ Components } & $\begin{array}{l}\text { Concentrations } \\
(\mathrm{mg} / \mathrm{L})\end{array}$ \\
\hline \multirow{5}{*}{ Macroelements } & $\mathrm{NH}_{4} \mathrm{NO}_{3}$ & 1650.000 \\
\hline & $\mathrm{KNO}_{3}$ & 1900.000 \\
\hline & $\mathrm{CaCl}_{2} \cdot 2 \mathrm{H}_{2} \mathrm{O}$ & 440.000 \\
\hline & $\mathrm{MgSO}_{4} \cdot 7 \mathrm{H}_{2} \mathrm{O}$ & 370.000 \\
\hline & $\mathrm{KH}_{2} \mathrm{PO}_{4}$ & 170.000 \\
\hline \multirow{9}{*}{ Microelements } & $\mathrm{KI}$ & 0.830 \\
\hline & $\mathrm{H}_{3} \mathrm{BO}_{3}$ & 6.200 \\
\hline & $\mathrm{MnSO}_{4} .4 \mathrm{H}_{2} \mathrm{O}$ & 22.300 \\
\hline & $\mathrm{ZnSO}_{4} \cdot 7 \mathrm{H}_{2} \mathrm{O}$ & 8.600 \\
\hline & $\mathrm{Na}_{2} \mathrm{MoO}_{4} \cdot 2 \mathrm{H}_{2} \mathrm{O}$ & 0.250 \\
\hline & $\mathrm{FeSO}_{4} \cdot 7 \mathrm{H}_{2} \mathrm{O}$ & 27.850 \\
\hline & $\mathrm{CoCl}_{2} \cdot 6 \mathrm{H}_{2} \mathrm{O}$ & 0.025 \\
\hline & $\mathrm{CuSO}_{4} .5 \mathrm{H}_{2} \mathrm{O}$ & 0.025 \\
\hline & $\mathrm{Na}_{2}$ EDTA. $2 \mathrm{H}_{2} \mathrm{O}$ & 37.250 \\
\hline \multirow{5}{*}{ Vitamins } & Myo-Inositol & 100.000 \\
\hline & Nicotinic Acid & 0.500 \\
\hline & Pyrotinic Acid & 0.500 \\
\hline & Thiamine-HCI & 0.100 \\
\hline & Glycine & 2.000 \\
\hline
\end{tabular}

MS medium, vitamins, $3 \%$ sucrose and $0.65 \%$ agar were used in all culture media. Distilled water was used for the preparation of the nurient medium. The $\mathrm{pH}$ of the nutrient medium was adjusted to $5.7 \pm 1$ using $1 \mathrm{~N} \mathrm{NaOH}$ and $1 \mathrm{~N}$ $\mathrm{HCl}$, followed by sterilization at 1.2 atmospheres pressure and at $120^{\circ} \mathrm{C}$ for 20 minutes. In the experiments, the explants were incubated under a white LED (LightEmitting Diode) light (1500 lux) at a temperature of $24^{\circ} \mathrm{C}$ and a 16 hour light photoperiod.

Regenerated shoots were transferred in culture medium containing $0.25 \mathrm{mg} / \mathrm{L}$ indole-3- acetic acid (IAA) for in vitro root formation, and then transferred to the aquarium environment to acclimate to external conditions. The aquarium conditions are set at $24^{\circ} \mathrm{C}$ temperature and 16 hours lighting. Also liquid fertilizer was added to the aquarium water.

Experiments were carried out in 100x10 mm petri dishes in 3 replicates. The data obtained from the study were analyzed using the SPSS 21 for Windows (Statistical Package for the Social Sciences) program. Duncan tests were applied for Post Hoc tests. Percent values were subjected to arcsin transformation prior to statistical analysis (Snedecor and Cochran, 1967).

\section{Results and Discussion}

The correct choice of explant variety in tissue culture studies has an important effect on the success of the study. For this reason, researchers have experimented with different explant varieties such as shoot tip (Sasidharan and Jayachitra, 2017; Bourrain, 2018), node (Dobranszki et al., 2017; Irshad et al., 2018), internode (Thul and Kukreja, 2010; Zhang et al., 2017), leaf (Mahindrakar et al., 2018) and root (Sharma et al., 2017).

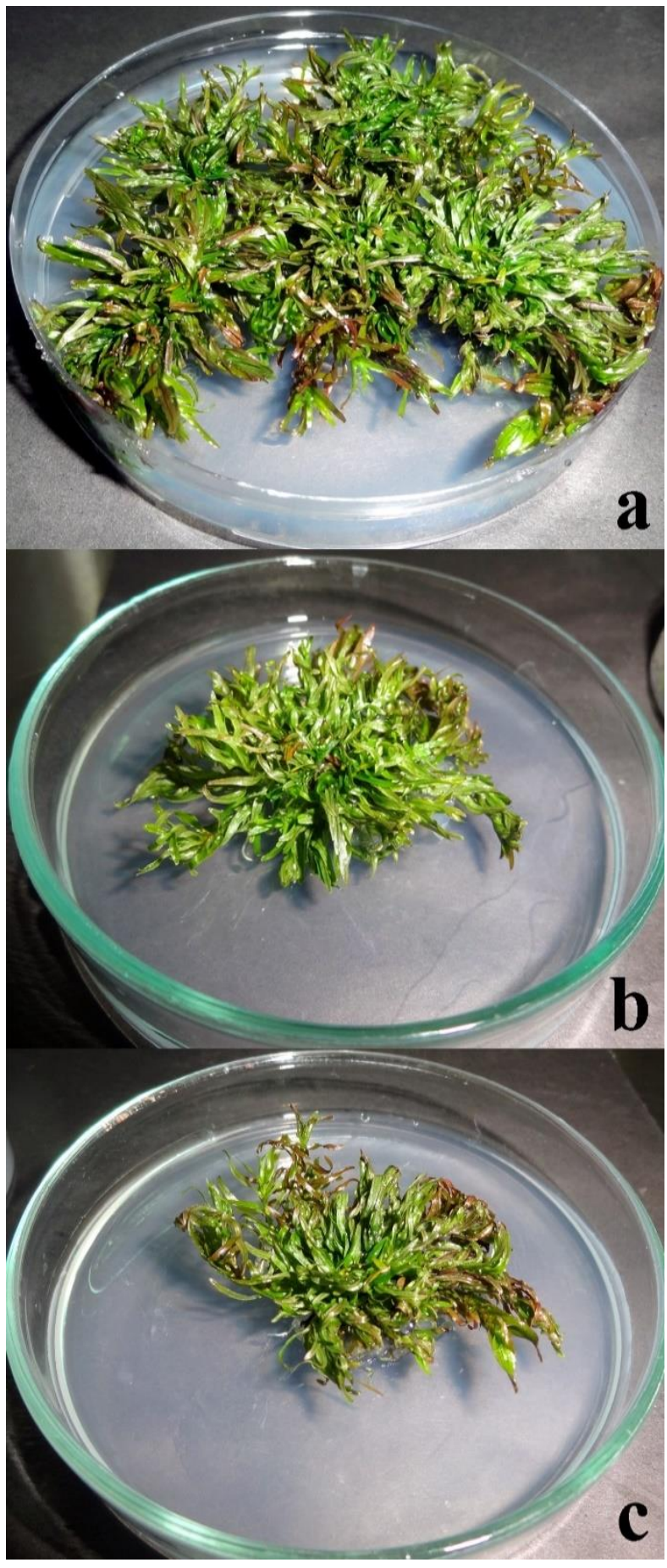

Figure 1. In vitro plant regeneration of $P$. erectus (a). Multiple shoot regeneration from shoot tip (a) and nodal (b) explants after 8 weeks of culture 
Table 2. Analysis of variance of shoot tip and nodal explants of P. erectus in MS medium containing different TDZ and 2,4-D

\begin{tabular}{|c|c|c|c|c|c|c|c|}
\hline \multirow{2}{*}{$\begin{array}{l}\text { Source of } \\
\text { variance }\end{array}$} & \multirow{2}{*}{$\begin{array}{c}\text { Degree } \\
\text { of } \\
\text { freedom }\end{array}$} & \multicolumn{2}{|c|}{$\begin{array}{l}\text { Shoot regeneration } \\
\text { frequency }(\%)\end{array}$} & \multicolumn{2}{|c|}{$\begin{array}{l}\text { Mean number of shoots } \\
\text { per explants }\end{array}$} & \multicolumn{2}{|c|}{ Mean shoot length $(\mathrm{cm})$} \\
\hline & & $\begin{array}{c}\text { Mean } \\
\text { square }\end{array}$ & $F$ value & $\begin{array}{c}\text { Mean } \\
\text { square }\end{array}$ & F value & $\begin{array}{c}\text { Mean } \\
\text { square }\end{array}$ & F value \\
\hline \multicolumn{8}{|c|}{ Shoot tip } \\
\hline Medium & 4 & 2518.76 & $33.99 * *$ & 356.41 & $80.92 * *$ & 0.08 & $9.28 * *$ \\
\hline Error & 10 & 74.104 & - & 4.405 & - & 0.01 & - \\
\hline General Total & 14 & - & - & - & - & - & - \\
\hline \multicolumn{8}{|c|}{$* *$ Significant at $p<0.01$ level } \\
\hline \multicolumn{8}{|c|}{ Nodal } \\
\hline Medium & 4 & 2102.01 & $28.37 * *$ & 427.80 & $70.56^{* *}$ & 0.03 & $18.62 * *$ \\
\hline Error & 10 & 74.10 & - & 6.06 & - & 0.002 & - \\
\hline General Total & 14 & - & - & - & - & - & - \\
\hline
\end{tabular}

In the present study, shoot tip and nodal explants of $P$. erectus were cultured in MS medium containing 0.10-0.80 $\mathrm{mg} / \mathrm{L} \mathrm{TDZ}+0.10 \mathrm{mg} / \mathrm{L}$ 2,4-D for rapid and multiple production under in vitro conditions. As a control group, these explants were also cultured in hormone-free MS nutrient medium. Similarly, the effect of TDZ hormone on in vitro production has been previously reported in plants such as Aronia mitschurinii (Mahoney et al., 2018) and Rauvolfia tetraphylla (L.) (Hussain et al., 2018).

After 15 days, regenereted shoots began to spread in culture media and multiple shoot formation was observed after four weeks. After eight weeks (Figure $1 \mathrm{a}, \mathrm{b}, \mathrm{c}$ ), the experiment was terminated and variance analysis was applied for percentage of shoot regeneration, number of shoots per explant and length of shoot (Table 2).

As seen in the analysis of variance, the statistically significant differences in the both explant types were found at $p<0.01$ level for shoot regeneration percentage, number of shoots per explant and shoot length (Table 2). The Duncan test results for determining the significance level of this difference are given in Figure 2.

The percentage of shoot regeneration of the shoot tip and nodal explants ranged from $33.31 \%$ to $100.00 \%$ and $38.89 \%$ to $100.00 \%$, respectively (Figure $2 \mathrm{~A}$ and $\mathrm{B}$ ). $100 \%$ shoot regeneration frequency was reached in MS medium containing $0.10,0.20$ and $0.40 \mathrm{mg} / \mathrm{L} \mathrm{TDZ}+0.10$ $\mathrm{mg} / \mathrm{L}$ 2,4-D in the both explants. The lowest shoot regeneration percentages in culture media containing plant growth regulator were detected in MS medium containing $0.80 \mathrm{mg} / \mathrm{L} \mathrm{TDZ}+0.10 \mathrm{mg} / \mathrm{L} \mathrm{2,4-D}$. In general, the shoot tip explants had a higher percentage of shoot regeneration than the nodal explants.

The number of shoots per explant ranged from 2.85 to 29.39 in the shoot tip explants (Figure 2 C) and from 2.72 to 32.24 in the nodal explants (Figure $2 \mathrm{D}$ ). The maximum number of shoots per explant was obtained in the MS medium containing $0.20 \mathrm{mg} / \mathrm{L} \mathrm{TDZ}+0.10 \mathrm{mg} / \mathrm{L} 2,4-\mathrm{D}$ for shoot tip (29.39), in the MS medium containing $0.10 \mathrm{mg} / \mathrm{L}$ $\mathrm{TDZ}+0.10 \mathrm{mg} / \mathrm{L} \mathrm{2,4-D}$ for nodal explant (32.24). In culture media containing hormones, the least number of shoots were recorded in MS medium supplemented with $0.80 \mathrm{mg} / \mathrm{L} \mathrm{TDZ}+0.10 \mathrm{mg} / \mathrm{L} \mathrm{2,4-D}$ in both explant types. The results showed that the increase in TDZ ratio used in the culture medium decreased shoot numbers from explants. Generally, nodal explants give higher number of shoots than shoot tip explants.

The length of shoots from the explants varied with the effects of growth regulators and statistically significant at $p<0.05$ level. In the medium containing growth regulators, the longest shoots for shoot tip explant was recorded as $1.76 \mathrm{~cm}$ in MS medium supplemented with $0.10 \mathrm{mg} / \mathrm{L}$ $\mathrm{TDZ}+0.10 \mathrm{mg} / \mathrm{L} 2,4-\mathrm{D}$ in the shoot explant, followed by in the MS medium supplemented with $0.20 \mathrm{mg} / \mathrm{L} \mathrm{TDZ} \mathrm{+}$ $0.10 \mathrm{mg} / \mathrm{L}$ 2,4-D $(1.73 \mathrm{~cm})$ (Figure $2 \mathrm{E})$. Short shoots were obtained in the nodal explant compared to the shoot tip explants. The highest shoot lengths for nodal explant $(1.64 \mathrm{~cm})$ were determined in MS medium supplemented with $0.10 \mathrm{mg} / \mathrm{L} \mathrm{TDZ}+0.10 \mathrm{mg} / \mathrm{L} \mathrm{2,4-D}$, followed by in the MS medium supplemented with $0.20 \mathrm{mg} / \mathrm{L} \mathrm{TDZ} \mathrm{+}$ $0.10 \mathrm{mg} / \mathrm{L} 2,4-\mathrm{D}(1.55 \mathrm{~cm}$ ) (Figure $2 \mathrm{~F}$ ).

The high rate of use of TDZ in culture media has adversely affected shoot length. Similar results were observed in Pyrus pyrifolia (Kadota and Niimi, 2003), Vitex trifolia (Ahmed and Anis, 2012) and R. tetraphylla (Hussain et al., 2018) plants, which were left in the TDZ medium for a long time. It has been reported that this inhibitory effect of TDZ is highly cytokine-like activity and may be due to the presence of the phenyl group in TDZ (Huetteman and Preece, 1993).

Regenerated shoots were transferred in culture medium containing $0.25 \mathrm{mg} / \mathrm{L}$ IAA for in vitro root formation. After four weeks, intense root formation was detected. The rooted plants are then left to aquarium conditions to acclimate to external conditions. Extensions were observed in the plant length and in the leaves after two weeks. At the end of four weeks the plants were successfully adapted to external conditions (100\% survival). As the MS basal medium was carefully removed from the plants, no contamination was detected in the aquarium environment. Similarly, the acclimatization of plants propagated in vitro to external conditions have been reported in Alternanthera sessilis (L.) (Gnanaraj et al., 2011), R. rotundifolia (Dogan, 2017), Pisum sativum L. (Sharma et al., 2017), Monochasma savatieri Franch ex Maxim (Zhang et al., 2017) and Enicostema axillare (Sasidharan and Jayachitra, 2017). 

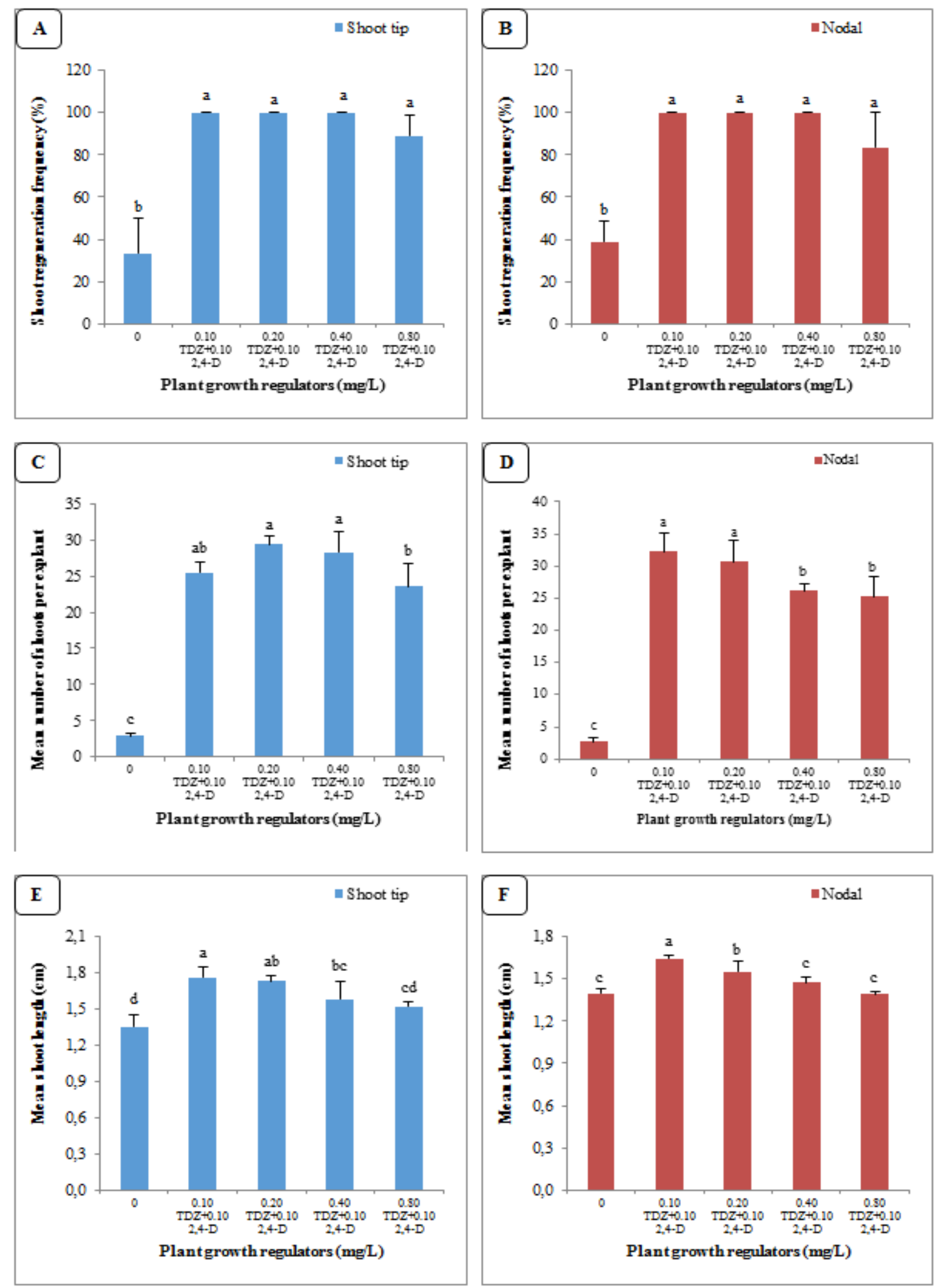

Figure 2. Effect of different combinations of TDZ and 2,4-D on in vitro shoot regeneration from shoot tip and nodal explants of $P$. erectus after eight weeks of culture. All values are the means of triplicates \pm SD $(n=3)$. Vertical bars indicate standard error of three separate experiments. Different letters indicate significantly different values (DMRT, $\mathrm{p}<0.05$ )

Consequently, multiple shoot formation from shoot and nodule explants of $P$. erectus was successfully achieved in culture media containing different TDZ and 2,4-D combinations. The best results for the average number of shoots were found in the lower combinations of TDZ and 2,4-D. This work presents an important protocol for the mass production of this plant. It can also help with gene transfer studies with this plant in the future. 


\section{References}

Ahmed MR, Anis M (2012). Role of TDZ in the Quick Regeneration of Multiple Shoots From Nodal Explant of Vitex trifolia L.an important medicinal plant. Appl Biochem Biotechnol 168: 957-966.

Baskaran P, Kumari A, Van Staden J (2017). In vitro Propagation Via Organogenesis and Synthetic Seeds of Urginea altissima (L.f.) Baker: a Threatened Medicinal Plant. 3 Biotech 8:18.

Bourrain L (2018). In Vitro Propagation of Actinidia melanandra Franch. and Actinidia rubricaulis Dunn. from Shoot Tip Explants. N Z J Crop Hortic Sci 46(2): 162-173.

Dobranszki J, Asboth G, Homoki D, Biro-Molnar P, da Silva JAT, Remenyik J (2017). Ultrasonication of In Vitro Potato Single Node Explants: Activation and Recovery of Antioxidant Defence System and Growth Responses. Plant Physiol Biochem 121: $153-160$.

Dogan M (2017a). Multiple Shoot Regeneration from Shoot Tip and Nodal Explants of Rotala rotundifolia (Buch-Ham. ex Roxb) Koehne. Ant J Bot 1(1): 4-8.

Doğan M (2017b). In Vitro Koşullarda Çoğaltılan Bazı Su Bitkilerinin Fitoremediasyon Potansiyellerinin Araştırılması. Karamanoğlu Mehmetbey Üniversitesi, Fen Bilimleri Enstitüsü, Biyoloji Anabilim Dalı, Karaman.

Emsen B, Dogan M (2018). Evaluation of Antioxidant Activity of In Vitro Propagated Medicinal Ceratophyllum demersum L. Extracts. Acta Sci Pol Hortoru 17(1): 23-33.

George EF (2008). Plant Tissue Culture Procedure - Background, Plant Propagation by Tissue Culture 3rd Edition, Editörler: George, E.F., Hall, M. ve De Klerk, G.J. 1, Springer, Netherlands.

Gnanaraj WE, Marimuthu J, Subramanian KM, Nallyan S (2011). Micropropagation of Alternanthera sessilis (L.) Using Shoot Tip and Nodal Segments. Iran J Biotechnol 9: 206-212.

Huetteman CA, Preece JE (1993). Thidiazuron: a Potent Cytokinin for Woody Plant Tissue. Plant Cell Tissue Organ Cult 33: 105119.

Hussain SA, Ahmad N, Anis M (2018). Synergetic effect of TDZ and BA on Minimizing the Post-Exposure Effects on Axillary Shoot Proliferation and Assessment of Genetic Fidelity in Rauvolfia tetraphylla (L.). Rend Lincei Sci Fis Nat 29: 109115 .

Hussain A, Qarshi IA, Nazir H, Ullah I (2012). Plant Tissue Culture: Current Status and Opportunities, Recent Advances in Plant in vitro Culture, Editörler: Leva, A. ve Rinaldi, L.M.R., 1, InTech, Croatia.

Irshad M, Rizwan HM, Debnath B, Anwar M, Li M, Liu S, He BZ, Qiu DL (2018). Ascorbic Acid Controls Lethal Browning and Pluronic F-68 Promotes High-frequency Multiple Shoot Regeneration from Cotyldonary Node Explant of Okra (Abelmoschus esculentus L.). HortScience 53(2): 183-190.

Kadota M, Niimi Y (2003). Efects of Cytokinin Types and Their Concentrations on Shoot Proliferation and Hyperhydricity in In Vitro Pear Cultivar Shoots. Plant Cell Tissue Organ Cult 72: 261-265.

Krishnan JJ, Gangaprasad A, Satheeshkumar K (2018). In Vitro Mass Multiplication and Estimation of Camptothecin (CPT) in Ophiorrhiza mungos L. var. angustifolia (Thw.) Hook. f.. Ind Crops Prod 119: 64-72.

Kumar V, Moyo M, Van Staden J (2016). Enhancing Plant Regeneration of Lachenalia viridiflora, a Critically Endangered Ornamental Geophyte with High Floricultural Potential. Sci Hortic 211: 263-268.

Mahindrakar A, Kumar R, Aswath C, Munikrishnappa PM (2018). Callusing and Regeneration Response of In Vitro Derived Leaf Explants of Gerbera (Gerbera jamesonii). Indian J Agricul Sci 88(6): 860-864.

Mahoney J, Apicella PV, Brand MH (2018). Adventitious Shoot Regeneration from In Vitro Leaves of Aronia mitschurinii and Cotyledons of Closely Related Pyrinae taxa. Sci Hortic 237: 135-141.

Murashige T, Skoog F (1962). A Revised Medium for Rapid Growth and Bioassays With Tobacco Tissue Cultures. Plant Physiol 15: 473-497.

Nazi S, Siddiquiland MF, Raza S (2018). Effect of Different Growth Regulators on In Vitro Propagation of Brassica napus L.. Pak J Bot 50(5): 1871-1876.

Neumann KH, Kumar A, Imani J (2009). Plant Cell and Tissue Culture - A Tool in Biotechnology, Principles and Practice, Springer-Verlag Berlin Heidelberg, 1, Germany.

Sasidharan P, Jayachitra A, (2017). Direct Shoot Bud Regeneration from Shoot Tip Explants of Enicostema axillare: An Important Medicinal Plant. Agrofor Syst 91(3): 471-477.

Sharma S, Gambhir G, Srivastava DK (2017). In Vitro Differentiation and Plant Regeneration from Root and Other Explants of Juvenile Origin in Pea (Pisum sativum L.). Legume Res 40(6): 1020-1027.

Shekhawat MS, Manokari M (2018). In Vitro Multiplication, Micromorphological Studies and Ex Vitro Rooting of Hybanthus enneaspermus (L.) F. Muell. - A Rare Medicinal Plant. Acta Bot Croat 77(1): 80-87.

Snedecor GW, Cochran WG (1997). Statistical Methods. The Iowa State University Press, Iowa. USA.

Thul ST, Kukreja AK, (2010). An Efficient Protocol for High-frequency Direct Multiple Shoot Regeneration from Internodes of Peppermint (Mentha x piperita). Nat Prod Commun 5(12): 1945-1946. 
Zhang YY, Chen YL, Zhang XH, da Silva JAT, Ma GH (2017). Adventitious Shoot Induction from Internode and Root Explants in a Semiparasitic Herb Monochasma savatieri Franch ex Maxim. J Plant Growth Regul 36(3): 799-804.

Cite this article: Doğan M (2019). In Vitro rapid propagation of an aquatic plant Pogostemon erectus (Dalzell) Kuntze. Anatolian Journal of Botany 3(1): 1-6. 